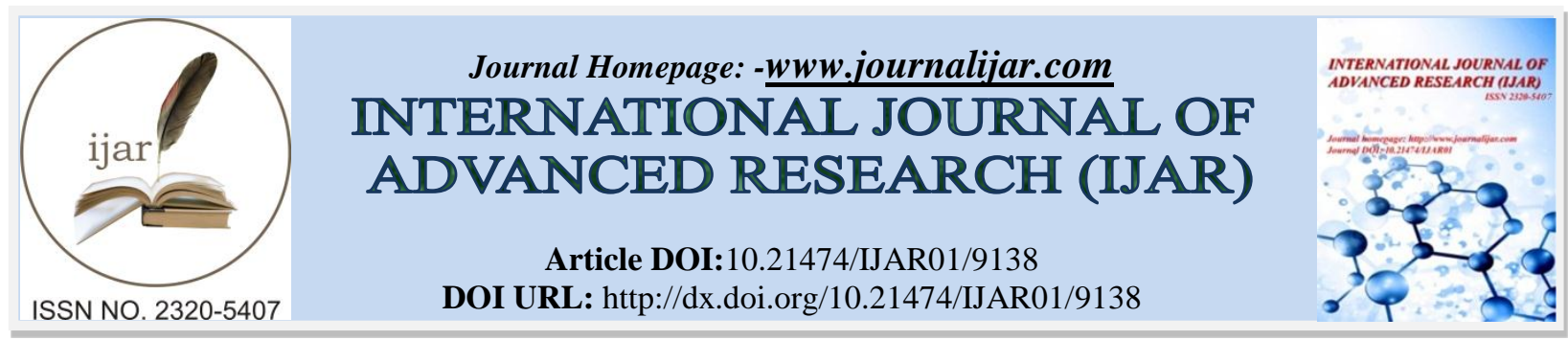

RESEARCH ARTICLE

\title{
MARKETING CAPABILITY, BUSINESS MODEL INNOVATION QUALITY AND SMES GROWTH PERFORMANCE.
}

1. Fajar University.

\author{
Nina Fapari Arif ${ }^{1}$, Abd.Rahman Kadir ${ }^{2}$, Jusni $^{2}$ and Abdul Razak Munir ${ }^{2}$.
}

2. Hasanuddin University.

\section{Manuscript Info}

Manuscript History

Received: 24 March 2019

Final Accepted: 26 April 2019

Published: May 2019

\section{Abstract}

This study focuses on marketing capabilities to SMEs Growth performance through Business Model Innovation Quality. Marketing capabilities have a significant positive effect on improving SMEs Growth performance through of business model innovations quality. This finding supports business model innovation quality as a mediator for improving SMEs Growth performance. This research was conducted in 250 respondents, namely SMEs that made digital sales by renewing their business models so as to have an impact on improving SME performance. Data analysis used using SEM-AMOS version 23.

Copy Right, IJAR, 2019,. All rights reserved.

\section{Introduction:-}

SMEs are very important for most economies in the world, especially developing countries. The World Bank states that Formal SMEs contribute $60 \%$ of total employment and up to $40 \%$ of national income (GDP) in developing countries, and these statistics will be significantly higher if taking into account Informal SMEs. In addition, the World Bank also estimates that 600 million workers will enter the global world for the next 15 years, especially in Asia and Africa. These estimates illustrate the importance of SMEs in shaping the economic landscape of developing countries. Given the important role of SMEs in economic growth, governments in developing countries continue to look for ways to strengthen SMEs and make them more successful (Ndiaye, Abdul Razak, Nagayev, \& $\mathrm{Ng}, 2018)$.

However, despite the initiative of policy makers to encourage the growth of SMEs, the role of SMEs in the private sector is often underestimated based on the Dahlberg Global Development Advisors report. The report shows the growth of SMEs in developing countries is often hampered by large capital for growth and expansion. Private businesses are important stakeholders who control most of their resources and capabilities (Ballou, Casey, Grenier, \& Heitger, 2012) Therefore SMEs must be able to innovate in their business models. Business model innovations are thought to produce higher returns than product or process innovations (Chesbrough \& Appleyard, 2007)

Business models are very important in sustainable competitive advantage and are a major influence in enhancing sustainable organizational performance. Sustainability issues, such as inequalities that have arisen and a decline in livelihoods (Lazaro \& Cordasco, 2017). Make the transformation towards a more sustainable economic system increasingly desirable. However, technological advances towards sustainability are increasing, and many companies find it difficult to meet their sustainability targets. Therefore innovation at the level of the business model is needed to harmonize incentives and income mechanisms to improve sustainable solutions (Lazaro \& Cordasco, 2017). 
Business models are strongly influenced by the ability to innovate. The ability to innovate is divided into two, namely technical and non-technical capabilities. Technical capabilities consist of developing new services, and developing technology. While non-technical capabilities consist of management, marketing and sales (Foroudi, Jin, Gupta, Melewar, \& Foroudi, 2016).

Quality of innovation is determined primarily by the quality of human resources who are able to learn continuously and keep up with trends in technology. The organizational structure is not rigid towards the bureaucracy that might hold back their creativity. For these challenges, the ability to innovate in digital content is very much needed (Nada \& Ali, 2015)

Some studies suggest that innovation and marketing are two important aspects of an organization's ability to obtain capital in a competitive market (Ngo \& O'Cass, 2013).. Consumers consider that the company can be trusted because of the products and services and the reputation of the company itself (Foroudi et al., 2016).

Innovation Ability is the ability to manage innovation processes starting from identifying needs and problems, research, development and commercialization of an innovation through diffusion to adoption by users. Describe the ability of innovation as an innovation value chain consisting of parts that are integrated with each other. The first is the development of ideas that can be carried out by parties inside or outside the company. The second is the conversion of ideas where ideas are chosen and developed into products or as processes.

\section{Innovation Capability}

Innovation was initially studied more on large companies, most traditionally associated with large multinational companies (Elkateb \& Black, 2006). The rise of innovation from small companies is relatively new, while large companies have an innovation advantage in economically intensive industrial capital while small companies have been recognized as important innovators in high-tech fields such as computers and biotechnology, but also instruments and other sectors

Small companies face special problems in the formulation of innovation strategies; they are related to deficiencies that arise due to limited resources and coverage of technological capabilities. Risks in responding to markets and technological opportunities and choosing appropriate actions at the right time (not too early or too late) make innovation strategies a key constraint for their management

Small and large companies have different roles in innovative activities depending on the resources and skills needed (Agabiti-Rosei et al., 1991).. Small companies have a number of unique features such as scarce resources, low market influence and informal communication, which make them different from large companies (Kaleka \& Morgan, 2016).. Which then adopts innovation strategies used by large companies (Kaleka \& Morgan, 2016).? The strengths of small companies are not within resources (at least physically), but the characteristics of their behavior, such as flexibility and management. The choice of innovation strategies carried out by the company itself varies greatly depending on the condition of the company and its response to environmental changes (Kaleka \& Morgan, 2016).

Innovation is essentially an activity conceptualization, and the idea of solving problems by bringing economic value to the company and social value to the community. So innovation departs from an existing one, and then gives added value. Innovation stems from things that seem trivial by opening eyes and ears to listen to the aspirations or complaints of consumers, employees, the environment and society. The subject of the application of innovation itself biases individuals, groups or companies. This means that bias can occur in companies that have very brilliant and innovative individuals or groups. But the ideal of the company becomes an institutionalized place for people who gather to exploit new ideas. (Ortiz-Cantú \& Pedroza-Zapata, 2007)

According to (Casadesus-masanell, 2018) innovation is an introduction to equipment, systems, laws, products or services, new production process technology, a new administrative structure or system, or a new planning program to be adopted by an organization. While the type of innovation is adoption behavior and the determining factor of the innovation 


\section{Business Model Innovation}

Innovation plays a very important role for organizational excellence. Innovation is achieved when we often ask: what and how at a high level, followed by a series of processes ranging from gathering creative ideas, processing creative ideas to innovative information, evaluating feasibility for implementation, and implementing innovation projects. All of these activities need to be managed effectively and efficiently through Innovation Management.

(Oeij, Dhondt, \& Gaspersz, 2016) suggests that Innovation management is a management discipline related to managing innovation in processes, products and services, organizations, to customers and markets. Innovation management can be used to develop innovation processes, products and services, organizations, and markets and customers. Without the right innovation process, it is not possible to produce effective and efficient products, so that it is not possible for us to be able to provide innovation value to the market and customers. Through value innovation, companies will be able to create new markets. Value innovation is defined as creating a quantum leap in buyer value while at the same time (dramatically) making a dramatic reduction in the cost structure of the industry.

The concept of a popular business model in the 1990s with dynamic research activities (Trimi \& Berbegal-Mirabent, 2012). This triggered a complex discussion in the journal Long Range Planning in 2010 and various literature reviews such as (Geissdoerfer, Vladimirova, \& Evans, 2018), , which was integrated, updated and synthesized. Since ecommerce boomed in the 1990s, innovative revenue mechanisms began to be developed. This is closely related to the business model. In this case it was initially used to communicate complex business ideas to potential investors in a short period of time (Geissdoerfer et al., 2018).

Based on the above, the business model continues to be developed to become a systemic analysis tool, planning, and communication configuration and implementation of one or more organizational units and related parts of their environment in the face of organizational complexity (Geissdoerfer et al., 2018)

At present the idea of a sustainable business model is increasingly seen as a source of competitive advantage (Porter \& Kramer, 2011). Thus it can be said that the concept of a sustainable business model may eventually replace competitive advantage (Kamboj, Goyal, \& Rahman, 2015). A sustainable business model as a modification of conventional business concepts, with certain characteristics and objectives modified. Merging 1) concepts, principles or definitions in various literatures have in common that they see goals that aim to be sustainable, 2) integrate into the position of corporate values, value creation in distribution activities, and or process mechanisms

\section{SMEs Growth Performance}

Many scientific articles and publications discuss the theory of SMEs, including classical theories and modern theories. Classical theory is supported by articles which include Anderson (1982). The classical theory of SME development predicts the profits of SMEs to decrease over time, and the rise in income of large companies will ultimately dominate economic development. Adherents to the classical theory advocate providing support for developing large companies compared to SMEs.

Modern theory emphasizes the importance of SMEs to economic growth and development. States those new industrial countries in East Asia such as Taiwan and South Korea have specialized businesses that adopt the experience of SMEs in Western Europe. Modern theory explains the important role of SMEs, namely: (1). Accelerating economic growth through the contribution of output to gross domestic product (GDP); (2). Reducing poverty through job creation. This is supported by empirical evidence that shows the positive relationship of SME growth with economic development

Many pros and cons arguments about the theory's thinking. Pro SME researchers do not support classical theory. They argue that SMEs can increase competition and entrepreneurship. Thus, SMEs have broad economic benefits in efficiency, innovation and productivity growth. They also argue that support from the government and other supporting institutions are the potential to realize SMEs as a driving force for economic growth and development. Many international aid agencies (including the World Bank) since the 1980s have provided support to MSMEs in accelerating economic growth and reducing poverty.

The World Bank supports modern theories by giving three arguments to support SMEs in underdeveloped countries, namely: (1). SMEs will increase competition and entrepreneurship, because it has external benefits to overall efficiency, innovation, and aggregate productivity growth; (2). SMEs are generally more productive than large 
companies, but their development has the potential to be hampered due to financial markets, institutional failures and a non-conducive macroeconomic environment; (3). The expansion of SMEs will open up many jobs than large companies, because SMEs are more labor intensive. The World Bank's pro-UKM policy for developing countries is proven through various support programs that have been carried out.

Many counter arguments have been raised against pro-SME policies. Critics question the assumption that SMEs can be used to measure economic growth and development. They argue that large companies have more advantages than SMEs, so they are better used in measuring growth. Some researchers also find that small businesses are no longer labor intensive or better at creating jobs than large companies (Beck, Demirguc-Kunt, \& Levine, 2005). They argue based on empirical facts that company size will respond to national institutional conditions. The fact is that large companies in countries that have financial institutions will develop better than SMEs (Beck et al., 2005). This argument raises concerns regarding efforts to support and improve the SME sector (Haltiwanger, Jarmin, \& Miranda, 2013); (Beck, Demirgüç-Kunt, \& Levine, 2003)

Several empirical studies show that SMEs contribute> 55\% of GDP and $>65 \%$ of total employment in high-income countries. Then SMEs contribute> $95 \%$ of employment and $70 \%$ of GDP in middle-income countries, and contribute more than $60 \%$ of GDP and more than $70 \%$ of total employment in low-income countries (Schlogl, 2004). Rwigema \& Karungu (1999) argues that SMEs are very dominant in the economy of a country. In the United States and the United Kingdom, Small Businesses play a strategic role in the economy because it accounts for a third of industrial employment with a lower percentage of output. SMEs in third world countries dominate economically active businesses, thus the prosperity of SMEs here is considered far more important than in the first world countries.

The role of SMEs in the economy cannot be underestimated, because it is the most important source of reducing poverty, increasing national economic growth, labor resources and increasing social status (Dahri, Kooh, \& Lim, 2014). (Hadi, Shafri, \& Mahir, 2014) also suggested that SMEs have an important role in economic growth and competitiveness. China is the country with the largest economic growth in the world, and SMEs are a key element in the economy that counts $99 \%$ of the total number of companies and $70 \%$ of total employment (Tang, Wang, \& Zhang, 2007). Most economies in Pakistan are SME-based economies (Minniti, Bygrave, \& Autio, 2005); (Kuratko \& Hodgetts, 2010); (Schlog1, 2004). In Pakistan, the SME sector represents 90\% of all companies in Pakistan, employs almost $80 \%$ of non-agricultural labor and shares $40 \%$ of annual GDP (Khan, I. A., \& Ghouri, 2011).

\section{Research Model and Development of Hypotheses Marketing Capability and SMEs Growth Performance}

The role of "controlling the market" and its influence on corporate performance has become an active field of research in marketing disciplines Song et al, 2007 at (Kamboj et al., 2015) suggests marketing capabilities help companies to create and maintain strong ties with customers and channel members. Marketing capabilities create a strong brand image that enables companies to produce superior performance (Kamboj et al., 2015).

H1: marketing capability has a positive and significant effect on SMEs Growth performance

\section{Marketing Capability and Business Model Innovation Quality}

Designing new business models requires creativity, insight and lots of intelligent information about customers and competitors. A suitable business model is rarely seen early for a developing industry: Good entrepreneurs / managers are well positioned, who have good but imperfect business model templates. Those who can learn and adjust are more likely to succeed. (Business model and innovation (Teece, 2010)

$\mathrm{H} 2$ : marketing capability has a positive and significant effect on the quality of business model innovation

Marketing Capability and SMEs Growth Performance

(Ngo \& O’Cass, 2013) Technical Innovation Capability (New service development, technology) Non-technical innovation capabilities (Managerial, sales, and marketing) H3: marketing capability has a positive and significant effect on SMEs Growth Performance through the Quality of Business Model Innovations 


\section{Methodology:-}

Research design

This research is categorized as applied research which is directed at solving specific problems at the time the research was conducted and basic / fundamental research directed at the development of science / theory (Sekaran 2000, 2011).

This research is explanatory research using quantitative research methods and using SEM-AMOS analysis tools.

\section{Population and sample}

Population is SMEs that make sales using Digital media in South Sulawesi The sample uses purposive sampling with the type of Judgment Sampling. The sample in this study was 250 UKM.

\section{Characteristics of Respondents}

Characteristics of Respondents based on Gender

\begin{tabular}{|l|l|l|l|}
\hline No & Gender & Frequency & Percentage (\%) \\
\hline 1 & Man & 73 & 29.2 \\
\hline 2 & Woman & 177 & 70.8 \\
\hline TOTAL & $\mathbf{2 5 0}$ & $\mathbf{1 0 0}$ \\
\hline
\end{tabular}

Source: Primary Data processed, $2019(\mathrm{~N}=250)$

Characteristics of Respondents by Age

\begin{tabular}{|l|l|l|l|}
\hline No & Age Level (Year) & Frequency & $\begin{array}{l}\text { Percentage } \\
(\boldsymbol{\%})\end{array}$ \\
\hline 1 & $<30$ years & 163 & 65 \\
\hline 2 & $31-40$ years & 62 & 25 \\
\hline 3 & 41-50 Years & 20 & 8 \\
\hline 4 & 5151 years and above & 5 & 2 \\
\hline TOTAL & $\mathbf{2 5 0}$ & $\mathbf{1 0 0 \%}$ \\
\hline
\end{tabular}

Source: Primary Data processed, $2019(\mathrm{~N}=250)$

\section{Measurement}

This study used an interval scale measurement scale in the form of Biporal_Adjective with susceptible scores (scores) 1 to 10, which have two extreme points namely agree and strongly disagree (Agree-Disagree Scale) (Ferdinand, 2006)

\section{Analysis and result:-}

\section{Normality}

The Normality Test was measured using the Critical ratio of \pm 2.58 at a significance level of $1 \%$ (0.01) (Ghozali, 2008). Based on the results of processed research data compared to these criteria, it can be concluded that the distribution of data is normal, both Univariate for each indicator and overall multivariate indicators

\begin{tabular}{|l|l|}
\hline Variable Indicator & Univariate \\
\hline X1.1: Product Conformity & 21.707 \\
\hline X1.2: Price & 31.954 \\
\hline X1.3: Distribution System & 10.608 \\
\hline X1.4: Marketing Communication & 21.727 \\
\hline X1.5: Marketing Planning & 24.430 \\
\hline X1.6: Marketing Activities & 26.369 \\
\hline Y1.1: Value Creation Innovation & 11.589 \\
\hline Y1.2: New Proposition Innovation & 0.051 \\
\hline Y1.3: New Revenue Models & 18.102 \\
\hline Y1.4: Calculating of Cost Strategy & 6.670 \\
\hline Y2.1: Finance & 15.972 \\
\hline Y2.2: Sales & 27.592 \\
\hline Y2.3: Competitive position & 31.226 \\
\hline
\end{tabular}




\begin{tabular}{|l|l|}
\hline Y2.4: Customer Growth & 21.722 \\
\hline Y2.5: Management Process & 12.943 \\
\hline Y2.6: New Market Improvement & 23.718 \\
\hline Multivariate & 52.878 \\
\hline
\end{tabular}

\section{Goodness of FIT}

The Goodness of fit test aims to see whether the data is in accordance with the model built in this study. GFI, CFI, TLI and RMSEA are benchmarks that meet the standards in this study. The model is said to be FIT with a Model if the GFI, CFI, TLI values are more than $\geq 0.09$ and RMSEA $\leq 0.08$. The FIT model in this study is GFI $=0.910$, CFI $=0.938, \mathrm{TLI}=0.916$ and $\mathrm{RMSEA}=0.076$

\section{Hypothesis testing}

\begin{tabular}{|c|c|c|c|c|c|c|}
\hline$x_{2}$ & & Standardized & SFL & Error & CR & AVE \\
\hline Variable & Indicator & Loading Factor & Quadrat & {$[\mathbf{E j}]$} & & \\
\hline \multirow[t]{6}{*}{ Marketing Capability } & X1.1 & 0.7 & 0.49 & 0.51 & \multirow[t]{6}{*}{0.89} & \multirow[t]{6}{*}{0.57} \\
\hline & $\mathrm{X} 1.2$ & 0.8 & 0.64 & 0.36 & & \\
\hline & $\mathrm{X} 1.3$ & 0.61 & 0.3721 & 0.6279 & & \\
\hline & $\mathrm{X} 1.4$ & 0.73 & 0.5329 & 0.4671 & & \\
\hline & $\mathrm{X} 1.5$ & 0.76 & 0.5776 & 0.4224 & & \\
\hline & $\mathrm{X} 1.6$ & 0.89 & 0.7921 & 0.2079 & & \\
\hline Total & & 4.49 & 3.4047 & 2.5953 & & \\
\hline \multirow[t]{4}{*}{ Business Model Innovation Quality } & Y1.1 & 0.81 & 0.6561 & 0.3439 & \multirow[t]{4}{*}{0.77} & \multirow[t]{4}{*}{0.5} \\
\hline & Y1.2 & 0.69 & 0.4761 & 0.5239 & & \\
\hline & Y1.3 & 0.62 & 0.3844 & 0.6156 & & \\
\hline & Y1.4 & 0.57 & 0.3249 & 0.6751 & & \\
\hline Total & & 2.69 & 1.8415 & 2.1585 & & \\
\hline \multirow[t]{6}{*}{ SMEs Growth Performance } & Y2.1 & 0.74 & 0.5476 & 0.4524 & \multirow[t]{6}{*}{0.88} & \multirow[t]{6}{*}{0.55} \\
\hline & Y2.2 & 0.85 & 0.7225 & 0.2775 & & \\
\hline & Y2.3 & 0.72 & 0.5184 & 0.4816 & & \\
\hline & Y2.4 & 0.66 & 0.4356 & 0.5644 & & \\
\hline & Y2.5 & 0.71 & 0.5041 & 0.4959 & & \\
\hline & Y2.6 & 0.77 & 0.5929 & 0.4071 & & \\
\hline Total & & 4.45 & 3.3211 & 2.6789 & & \\
\hline Limit Accepted & & & & & $\geq 0.70$ & $\geq 0.50$ \\
\hline
\end{tabular}

H1: marketing capability has a positive and significant effect on SMEs Growth performance. The results show that Marketing Capability has a positive and significant effect on SMEs Growth Performance $(\mathrm{B}=0.081, \mathrm{P}<0.05)$. H1 Received

H2: marketing capability has a positive and significant effect on the quality of business model innovation. The results show that Marketing Capability has a positive and significant effect on Business Model Innovation Quality $(\mathrm{B}=0.097, \mathrm{P}<0.05)$. H2 Accepted

H3: marketing capability has a positive and significant effect on SMEs Growth Performance through the Quality of Business Model Innovations. The results show from the results of the Sobel Test statistical tests that marketing capability has a positive and significant effect on SME Performance Improvement through Business Model Innovation Quality (Z-test $=5.673>1.80)$. H3 Accepted.

Hypothesis testing

\begin{tabular}{|l|l|l|}
\hline Hypothesis & Coefficient & Result \\
\hline $\begin{array}{l}\text { Direct Effect } \\
\text { Marketing Capability (X1) } \rightarrow \text { SMEs Growth Performance (Y2) }\end{array}$ & $0.081^{*}$ & Accepted \\
\hline Marketing Capability (X1) $\rightarrow$ Business Model Innovation Quality (Y1) & $0.097^{*}$ & Accepted \\
\hline Indirect Effect & $5.673^{*}$ & Accepted \\
\hline
\end{tabular}


Marketing Capability (X1) $\rightarrow$ Business Model Innovation Quality (Y1) $\rightarrow$ SMEs Growth Performance (Y2)

\section{Conclusion and Implication:-}

The findings show that marketing ability influences the Quality of Business Model Innovation and on improving the performance of SMEs. Besides that the Quality of Business Model Innovation moderates marketing capabilities to SME Growth Performance.

Marketing Capability as an integrative process, where companies use tangible and intangible resources to understand complex consumer specific needs, achieve product differentiation relative to competition, and achieve superior brand equity (Magazù, Migliardo, \& Benedetto, 2011)

A company develops its marketing capabilities when it can combine individual skills and knowledge of its employees along with available resources (Vorhies, 2007). A company that spends more resources to interact with customers can increase their ability to "feel the market". Such capabilities are very difficult to replicate for competing companies (Raes \& ter Steege, 2007). Thus marketing capability is considered an important source for increasing the company's competitive advantage.

The role of "controlling the market" and its influence on corporate performance has become an active field of research in marketing disciplines (Song et al, 2008) Song et al, 2007 suggests marketing capabilities help companies to create and maintain strong ties with customers and channel members. Marketing capabilities create a strong brand image that enables companies to produce superior performance.

The marketing literature shows that companies use the ability to convert resources into output based on their marketing mix strategies and marketing capabilities related to their business performance (Nath, Nachiappan, \& Ramanathan, 2010).

Traditional Marketing Measurements, in the literature, always measure marketing capabilities using indicators based on subjective surveys, such as competitor knowledge, advertising effectiveness, and managing long-lasting customer relations (Nath et al., 2010). There is debate in the literature about the accuracy of the results derived based on managers' perceptions.

Marketing Capability has a positive relationship with continuous innovation (Kamboj et al., 2015) and in this case sustainable innovation is a business model innovation that is carried out in a sustainable manner.

\section{Research Limitations}

This study does not focus on one type of industry that is similar. So recommending further researchers to be able to examine each sector in SMEs in improving the performance of SMEs

\section{References:-}

1. Agabiti-Rosei, E., Muiesan, M. L., Rizzoni, D., Romanelli, G., Beschi, M., \& Castellano, M. (1991). Regression of cardiovascular structural changes after long-term antihypertensive treatment with the calcium antagonist nitrendipine. Journal of Cardiovascular Pharmacology. https://doi.org/10.1097/00005344-199100185-00003

2. Ballou, B., Casey, R. J., Grenier, J. H., \& Heitger, D. L. (2012). Exploring the strategic integration of sustainability initiatives: Opportunities for accounting research. Accounting Horizons. https://doi.org/10.2308/acch-50088

3. Beck, T., Demirguc-Kunt, A., \& Levine, R. (2005). SMEs, growth, and poverty: Cross-country evidence. Journal of Economic Growth. https://doi.org/10.1007/s10887-005-3533-5

4. Beck, T., Demirgüç-Kunt, A., \& Levine, R. (2003). Law, endowments, and finance. Journal of Financial Economics. https://doi.org/10.1016/S0304-405X(03)00144-2

5. Casadesus-masanell, R. (2018). Business Model Innovation and Competitive Imitation: The Case of SponsorBased Business Models The Harvard community has made this article openly available . Please share how this access benefits you . Your story matters . Business Model Innovation and C. https://doi.org/10.1002/smj.2022

6. Chesbrough, H. W., \& Appleyard, M. M. (2007). Open Innovation and Strategy. California Management Review. https://doi.org/10.2307/41166416 
7. Dahri, M. K., Kooh, M. R. R., \& Lim, L. B. L. (2014). Water remediation using low cost adsorbent walnut shell for removal of malachite green: Equilibrium, kinetics, thermodynamic and regeneration studies. Journal of Environmental Chemical Engineering. https://doi.org/10.1016/j.jece.2014.07.008

8. Elkateb, S., \& Black, W. (2006). Building a Wordnet for Arabic. In Proceedings of The fifth international conference on Language Resources and Evaluation.

9. Ferdinand, P. D. A. (2006). Metode Penelitian Manajemen: Pedoman Penelitianuntuk Skripsi, Tesis dan Disertasi Ilmu Manajemen. BP Undip 2. https://doi.org/10.4304/jcp.8.2.326-333

10. Foroudi, P., Jin, Z., Gupta, S., Melewar, T. C., \& Foroudi, M. M. (2016). Influence of innovation capability and customer experience on reputation and loyalty. Journal of Business Research, 69(11), 4882-4889. https://doi.org/10.1016/j.jbusres.2016.04.047

11. Geissdoerfer, M., Vladimirova, D., \& Evans, S. (2018). Sustainable business model innovation: A review. Journal of Cleaner Production, 198, 401-416. https://doi.org/10.1016/j.jclepro.2018.06.240

12. Hadi, S. J., Shafri, H. Z. M., \& Mahir, M. D. (2014). Modelling LULC for the period 2010-2030 using GIS and remote sensing: A case study of Tikrit, Iraq. In IOP Conference Series: Earth and Environmental Science. https://doi.org/10.1088/1755-1315/20/1/012053

13. Haltiwanger, J., Jarmin, R. S., \& Miranda, J. (2013). Who creates jobs? Small versus large versus young. Review of Economics and Statistics. https://doi.org/10.1162/REST_a_00288

14. Kaleka, A., \& Morgan, N. A. (2016). How marketing capabilities and current performance drive strategic intentions in international markets. Industrial Marketing Management, 1-14. https://doi.org/10.1016/j.indmarman.2017.02.001

15. Kamboj, S., Goyal, P., \& Rahman, Z. (2015). A Resource-Based View on Marketing Capability, Operations Capability and Financial Performance: An Empirical Examination of Mediating Role. Procedia - Social and Behavioral Sciences, 189, 406-415. https://doi.org/10.1016/j.sbspro.2015.03.201

16. Khan, I. A., \& Ghouri, a. M. (2011). Managerial skills and organizational learning in SMEs of Pakistan. Indian Journal of Commerce \& Management Studies, 2(4), 61-69.

17. Kuratko, D. F., \& Hodgetts, R. M. (2010). Entrepreneurship theory process and practice. Business (10th ed.). https://doi.org/0-495-91356-1

18. Lazaro, L. E., \& Cordasco, F. A. (2017). Treatment. In Shoulder and Elbow Injuries in Athletes: Prevention, Treatment and Return to Sport. https://doi.org/10.1016/B978-0-323-51054-7.00021-X

19. Magazù, S., Migliardo, F., \& Benedetto, A. (2011). Puzzle of protein dynamical transition. Journal of Physical Chemistry B. https://doi.org/10.1021/jp111421m

20. Minniti, M., Bygrave, W. D., \& Autio, E. (2005). Global Entrepreneurship Monitor: 2005 Executive Report. London.

21. Nath, P., Nachiappan, S., \& Ramanathan, R. (2010). The impact of marketing capability, operations capability and diversification strategy on performance: A resource-based view. Industrial Marketing Management, 39(2), 317-329. https://doi.org/10.1016/j.indmarman.2008.09.001

22. Ndiaye, N., Abdul Razak, L., Nagayev, R., \& Ng, A. (2018). Demystifying small and medium enterprises' (SMEs) performance in emerging and developing economies. Borsa Istanbul Review. https://doi.org/10.1016/j.bir.2018.04.003

23. Ngo, L. V., \& O'Cass, A. (2013). Innovation and business success: The mediating role of customer participation. Journal of Business Research. https://doi.org/10.1016/j.jbusres.2012.03.009

24. Oeij, P. R. A., Dhondt, S., \& Gaspersz, J. (2016). Mindful infrastructure as an enabler of innovation resilience behaviour in innovation teams. Team Performance Management. https://doi.org/10.1108/TPM-12-2015-0058

25. Ortiz-Cantú, S. J., \& Pedroza-Zapata, Á. R. (2007). Cuarto de guerra para la innovación tecnológica. Repositorio Institucional Del ITESO.

26. Porter, M. E., \& Kramer, M. R. (2011). Creating Shared Value: How to reivent capitalism - and Unleash a Wave of Innovation and Grown. In Is Increasing Profits the Only Social Responsibility.

27. Raes, N., \& ter Steege, H. (2007). A null-model for significance testing of presence-only species distribution models. Ecography. https://doi.org/10.1111/j.2007.0906-7590.05041.x

28. Schlogl, H. (2004). Small and Medium Enterprises Seizing The Potential, 46-48.

29. Sekaran 2000. (2011). Information needs and Information seeking behaviors of Social Science Graduate Students in Malaysian Public Universities. International Journal of Business and Social Science.

30. Tang, Y., Wang, P., \& Zhang, Y. (2007). Marketing and business performance of construction SMEs in China. Journal of Business \& Industrial Marketing, 22(2), 118-125. https://doi.org/10.1108/08858620710730230 
31. Teece, D. J. (2010). Technological innovation and the theory of the firm: The role of enterprise-level knowledge, complementarities, and (dynamic) capabilities. In Handbook of the Economics of Innovation. https://doi.org/10.1016/S0169-7218(10)01016-6

32. Trimi, S., \& Berbegal-Mirabent, J. (2012). Business model innovation in entrepreneurship. International Entrepreneurship and Management Journal, 8(4), 449-465. https://doi.org/10.1007/s11365-012-0234-3

33. Vorhies, d. W. (2007). Market-based dynamic capabilities and firm performance. North.

\section{Appendix}

UJI MODEL

Statistical Measure

Chi Square=355.915

Signifikansi $=.000$

$D F=101$

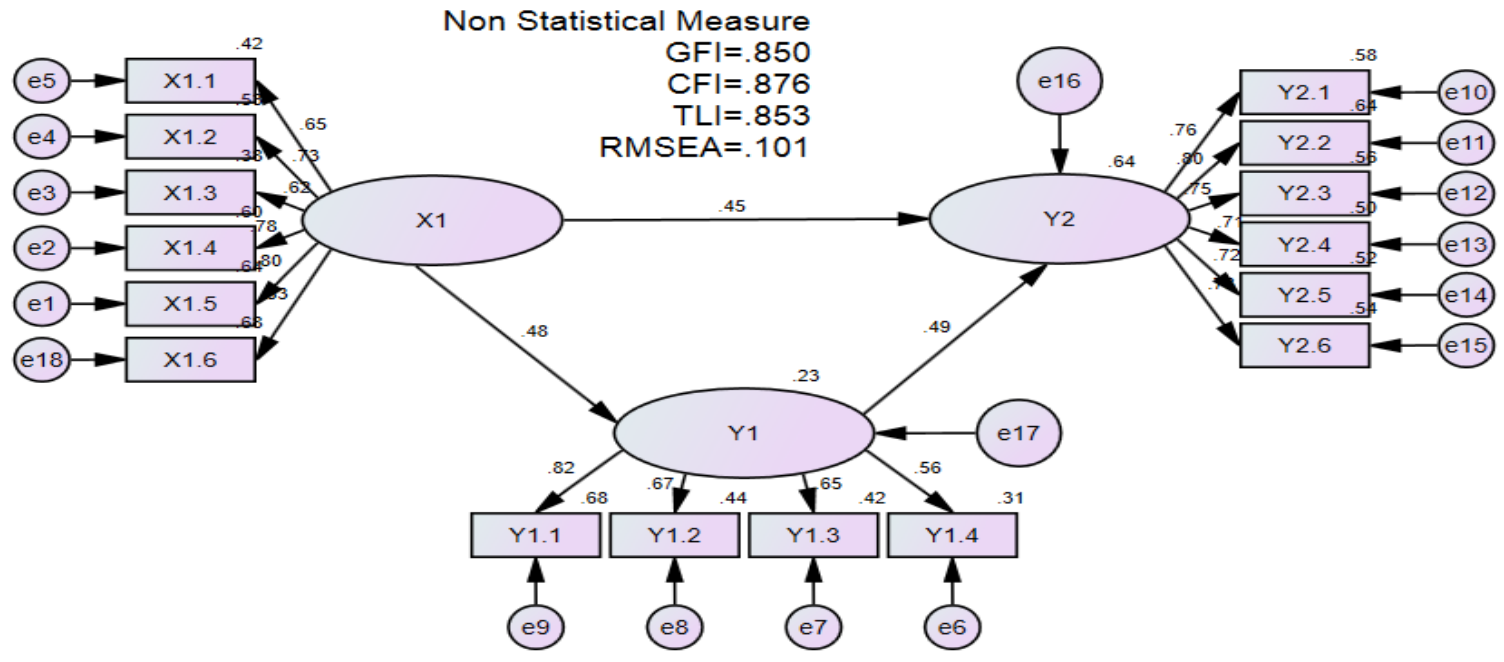

After Modification

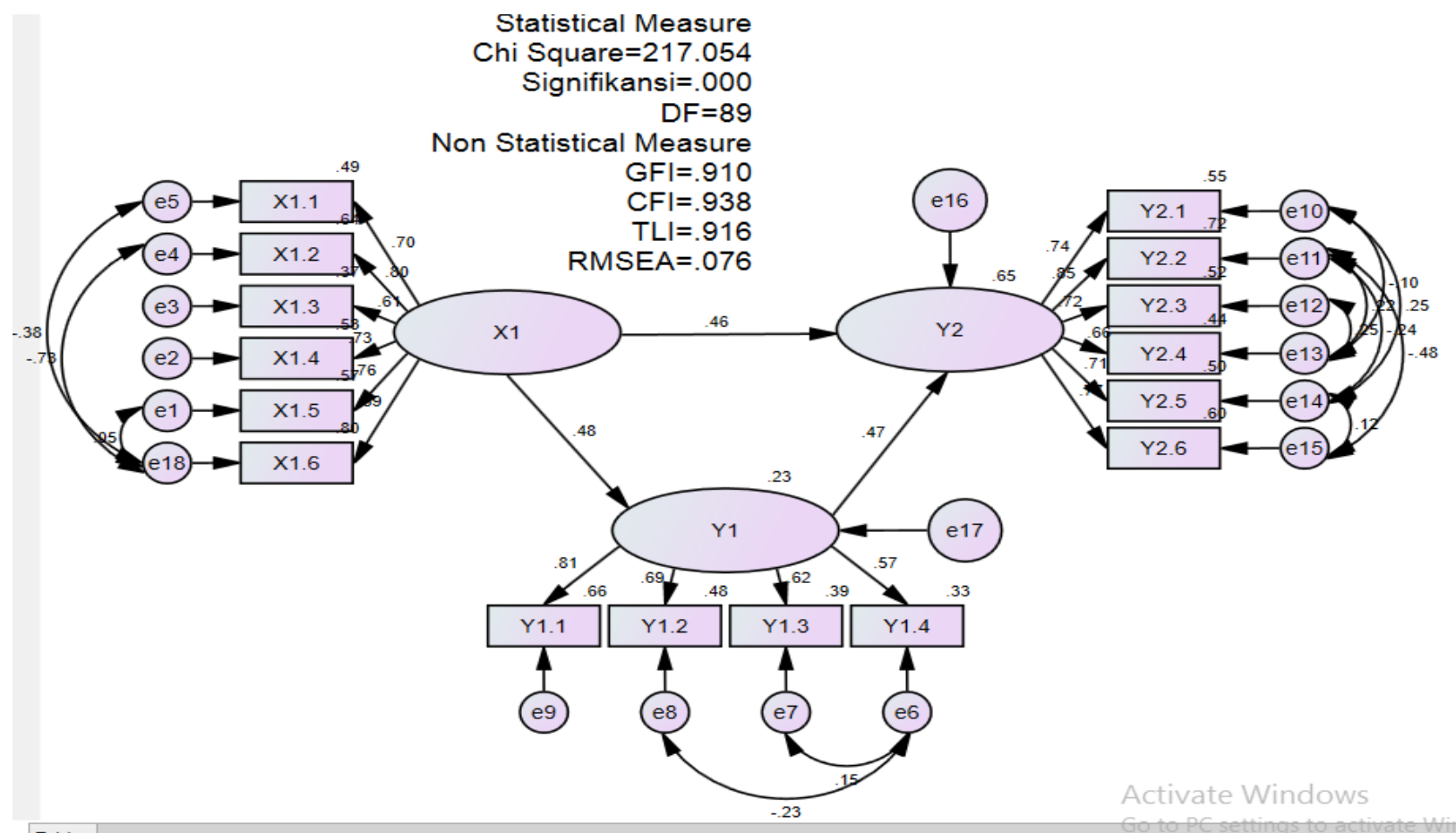




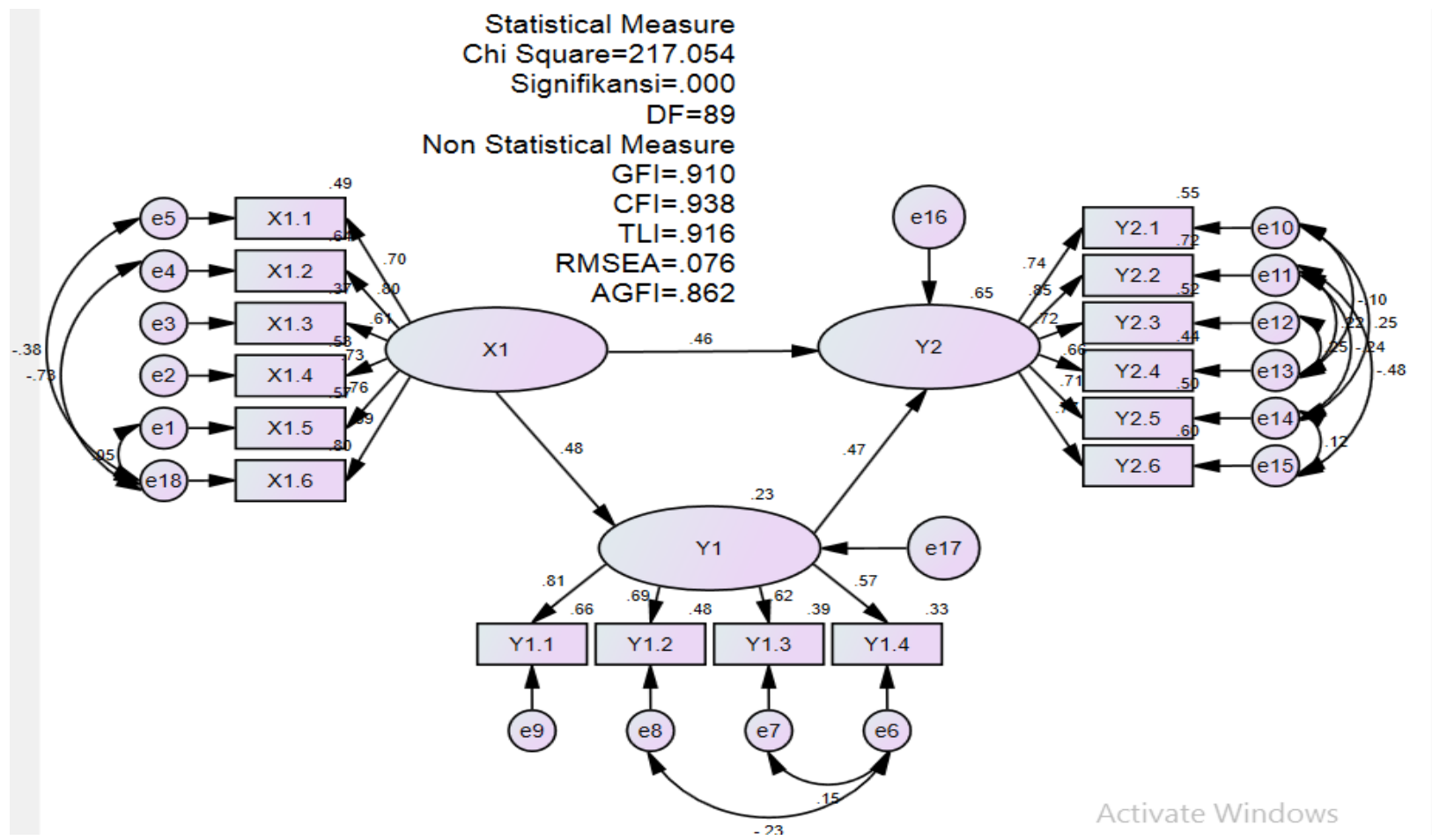

